Invited review

\title{
Perspectives of antimony compounds in oncology
}

\author{
Pankaj SHARMA ${ }^{1,3}$, Diego PEREZ ${ }^{1}$, Armando CABRERA ${ }^{1}$, Noe ROSAS $^{1}$, Jose Luis ARIAS ${ }^{2}$ \\ ${ }^{1}$ Instituto De Química, UNAM Circuito Exterior, Coyoacan México DF.04510; ${ }^{2}$ Facultad de Estudios Superiores Cuautitlán, UNAM, Cuautitlan \\ Izcalli, Estado de México 54700, Mexico
}

\section{Key words}

antimony; organoantimony; antitumoral; leishminiatic drugs

${ }^{3}$ Correspondence to Dr Pankaj SHARMA. Phn 52-55-5622-4556.

E-mail pankajsh@servidor.unam.mx

Received 2008-03-10

Accepted 2008-04-28

doi: $10.1111 / \mathrm{j} .1745-7254.2008 .00818 . x$

\begin{abstract}
Antimony, a natural element that has been used as a drug for over more than 100 years, has remarkable therapeutic efficacy in patients with acute promyelocytic leukemia. This review focuses on recent advances in developing antimony anticancer agents with an emphasis on antimony coordination complexes, $\mathrm{Sb}$ (III) and $\mathrm{Sb}(\mathrm{V})$. These complexes, which include many organometallic complexes, may provide a broader spectrum of antitumoral activity. They were compared with classical platinum anticancer drugs. The review covers the literature data published up to 2007. A number of antimonials with different antitumoral activities are known and have diverse applications, even though little research has been done on their possibilities. It might be feasible to develop more specific and effective inhibitors for phosphatase-targeted, anticancer therapeutics through the screening of sodium stibogluconate (SSG) and potassium antimonyltartrate-related compounds, which are comprised of antimony conjugated to different organic moieties. For example, SSG appears to be a better inhibitor than suramin which is a compound known for its antineoplastic activity against several types of cancers.
\end{abstract}

\section{Introduction}

Antimony, a neutral substance that has been used as a drug for over 100 years, has remarkable therapeutic efficacy in patients with acute promyelocytic leukemia (APL). It exerts apoptosis in dose- and time-dependent manner. Advances in biocoordination chemistry are crucial for improving the design of compounds to reduce toxic side-effects and to understand their mechanisms of action. A great number of metallic complexes display a pronounced antitumoral activity, which makes them of a high interest for applications in the treatment of different types of cancer ${ }^{[1]}$. This research began in 1969 with the discovery of cisplatin by Rosenberg et $a l^{[2]}$ in the treatment of testicle and ovary cancers, despite the fact that metal (oid)-containing compounds have been used historically as medicines for several thousands of years, especially in Chinese and Indian traditional medicine.

The clinical success of cisplatin and other platinum complexes is limited by the significant side-effects or intrinsic resistance ${ }^{[3]}$. Therefore, much attention has focused on designing new coordination compounds with improved phar- macological properties and a wide range of antitumoral activities. Strategies for developing new anticancer agents include the incorporation of carrier groups that can target tumor cells with high specificity. In an attempt to beat the resistance pathways that have evolved to eliminate the drug, developing new complexes that bind to DNA in a fundamentally different manner than cisplatin is also of interest. It has been widely accepted that the organic ligands associated with the metal atom in these complexes play an important role during their transport and assimilation at the membrane level and inside the cell.

To date, practically all transition and main group metals have been tested for antitumoral properties, and interestingly, a number of them have been shown marginal to good activity towards standard animal tumors ${ }^{[4-9]}$. Within the main group metal, inorganic and organometallic complexes of gallium, germanium ${ }^{[10,11]}$, and tin have been the focus of most antitumoral studies. Gielen et al recently published antitumoral studies of a series of germanium rings against different human cancer cell lines. ID $_{50}$ (Infectous dose 50) values 
of most of the compounds were comparable with clinically employed drugs doxorubicin and cisplatin ${ }^{[12]}$. The same group has patented tin carboxylate complexes for their antitumoral properties that were later renewed ${ }^{[13,14]}$. Recently, chemical and biotechnological developments in organotin cancer chemotherapy emphasizing the coordinating ability of organotin compounds towards DNA and the action mode of organotins in cancer chemotherapy was reviewed ${ }^{[15]}$. In contrast, antimony compounds ${ }^{[16-17]}$ appear to have not been as well documented as other metal-containing species, despite the fact that organoantimonials have been used successfully for more than half a century in the treatment of leishmaniases ${ }^{[18-21]}$. Leishmaniases are ineffective parasitic diseases that are injected into mammals via sand flies, which are endemic in 88 countries, and mainly affect developing countries. Pentavalent antimonials, including antimony bis(4,5-dihydroxybenzene-3,5-disulphonate) Stibophen (Scientific coorp. USA), antimony (III) gluconate (Triostam; Canton Chem, USA), meglumine antimoniate (Glucantime; Aventis, France), and sodium stibogluconate (SSG; Pentostam; GlaxoSmithKline, US and UK) have been used for a long time as antileishmanial drugs. In spite of several limitations, including side-effects, need for daily parentral administration, and drug resistance, antimonials are still firstline drugs (Figure 1). The metabolism and mechanisms of action are still being investigated. It is not clear whether the final active form of pentavalent antimonials is $\mathrm{Sb}(\mathrm{V})$ or $\mathrm{Sb}$ (III), although recent studies suggest that pentavalent antimony acts as a prodrug that is converted to active and more toxic trivalent antimony, and thiols may act as a reducing agent in this conversion ${ }^{[22]}$. Some reports have suggested the intrinsic antileishmanial activity of $\mathrm{Sb}(\mathrm{V})$, which forms a complex with adenine ribonucleoside. Sb-ribonucleoside complexes may act as inhibitor of leishmania purine transporters or penetrate inside the parasite and then interfere with the purine nucleoside metabolism ${ }^{[23]}$.

During the last decade, there has been progress made towards the improvement of antimonial chemotherapy for leishmaniases, but the application of antimonials as antitumoral agents needs attention.

\section{Trivalent antimony compounds}

In the mid 1960s, Hsu et al ${ }^{[24-26]}$ reported the antitumoral activity of inorganic compounds of antimony and demonstrated that some $\mathrm{Sb}(\mathrm{III})$ with aminopolycarboxy ligands increased the life span of mice bearing the Ehrlich ascites tumor and spindle sarcoma. It was later reported that some tungstoantimonates with complicated compositions exhibited antitumoral activity ${ }^{[27,28]}$.
Nitrogen mustard cyclophosphamide (Figure 2) is an alkylating agent reported to possess significant antitumoral activity in selected malignant neoplasms; however, its 1:1 adduct with $\mathrm{SbCl}_{3} \mathrm{~L}$ presented no activity against L1210 leukemia and Ehrlich ascites tumor, similar to the inactivity of other metal coordination compounds ${ }^{[29]}$.

A series of antimony (III) complexes along with other metal ion complexes, that is, $\mathrm{Co}, \mathrm{Ni}, \mathrm{Sn}$, and $\mathrm{Pb}$ with different polydentate carboxylic acids have also been investigated for their antitumoral action. Preliminary results have indicated that the uncoordinated ligands as such are not as potent as antimony complexes with these ligands, showing the presence of $\mathrm{Sb}$ (III) for activity. Of the other metal ions investigated with these ligands, only the antimony (III) species have shown activity ${ }^{[30,31]}$.

The cytotoxicity of $\mathrm{NH}_{4}(\mathrm{Sb}$ [Hdtpa]) was examined in human promyelocytic leukemia (HL-60) cells. Complexes at 1 , 10 , and $100 \mu \mathrm{g} / \mathrm{mL}$ showed $18 \%, 70 \%$, and $100 \%$ cell inhibition within $24 \mathrm{~h}$, respectively. The antitumoral activity of $\mathrm{NH}_{4}(\mathrm{Sb}$ [Hdtpa]) (Figure 3) (30 mg/kg) towards solid experimental animal tumors (S180) in mice reduced the weight of the tumors to $74 \%$ of that of the control values on $\mathrm{d} 9$ after tumor transplantation ${ }^{[30]}$.

In vitro antitumoral activity of antimony (III) nitrilotriacetate complexes ( nitriloacetate compound shown in Figure 4) against Ehrlich adenocarcinoma (EAC) in mice was studied. Compound $\left(\mathrm{NH}_{4}\right)_{2} \mathrm{Sb}(\mathrm{Nta})(\mathrm{HNta})-\mathrm{nH}_{2} \mathrm{O}(\mathrm{I})$ and $\mathrm{Na}_{2} \mathrm{Sb}$ (Nta) (HNta) $\times 2 \mathrm{H}_{2} \mathrm{O}$ (II) produced a significant $(60 \%-90 \%)$ increase in the survival rate of test mice with ascetic EAC, at an optimum therapeutic dose of $25-50 \mathrm{mg} / \mathrm{kg}$ in the absence of significant toxicity in this dose range. The results showed good prospects in the search for new antitumoral agents among $\mathrm{Sb}(\mathrm{III})$ complexes with aminopolycarboxy ligands ${ }^{[32]}$.

Similarly, antimony (s-benzyldithiocarbazate) complexes display antitumoral agents against melanoma (skin cancer cells $)^{[33]}$.

The toxicity of a novel water stable antimony (III) complex with heterocyclic thioamide, 2-mercaptopyrimidine (pmtH) (Figure 5) of formula $\left.\mathrm{Sb}(\mathrm{pmt})_{3}\right] 0.5\left(\mathrm{CH}_{3} \mathrm{OH}\right)$, against tumor pleiomorphic cells was studied. Pleiomorphic cells were isolated from a leiomyosarcoma tumor in the Wistar rat (chemical carcinogenesis using 3,4-benzopyrene BaP). The result showed that the compound did not destroy or prevent multiplication in vitro leiomyosarcoma cells at low doses. The antimetastatic capability study showed that the compound had shown inhibition of cancer cell-induced aggregation up to the value of $10 \%$ in all $\mathrm{mmol} / \mathrm{L}$ concentrations tested $^{[34]}$.

Recently, new antimony (III) complexes with the hetero- 
(a)<smiles>O=[N+]([O-])c1cc2c(c([S+](=O)(=O)O)c1)O[Sb-]1(Oc3cc(S(=O)(=O)[O-])cc([S+](=O)(=O)[O-])c3O1)O2</smiles>

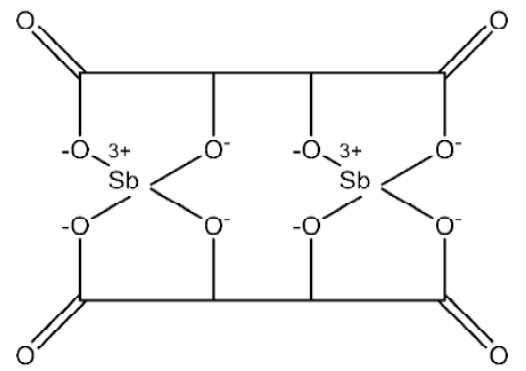

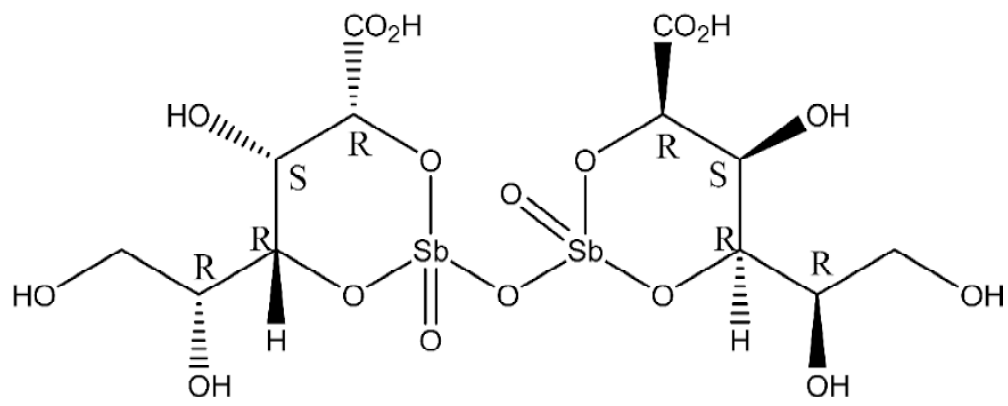

(b)<smiles>O=C([O-])C(S[Sb]1SC(C(=O)[O-])C(C(=O)[O-])S1)S[Sb]1SC(C(=O)[O-])C(C(=O)[O-])S1</smiles>

(c)

Figure 1. Some antileishmanial compounds of antimony (a) Antimony bis(4,5-dihydroxybenzene-3,5-disulphonate) (Stibophen) and Antimony (III) tartarate (Tartar emetic), (b) SSG (Pentostam), (c) Antimony-2,3-dimercaptosuccinate (Astiban)

cyclic thiones 2-mercapto-benzimidazole, 5-ethoxy-2mercapto-benzimidazole, 2-mercapto-thiazolidine, and 2mercapto-3,4,5,6-tetrahydro-pyrimidine were tested in vitro for their inhibitory effects on the proliferation of murine leukemia cells(L1210), murine mammary carcinoma cells(FM3A), human T-lymphocyte cells (Molt4/C8, CEM), and human cervix carcinoma cells $(\mathrm{HeLa})^{[35]}$. Complexes showed a pronounced cytostatic activity against these tumor cell lines.
Surprisingly, antimony (III) thione complexes consistently showed selective antiproliferative activity against HeLa cells. Their antiproliferative activity against cervix carcinoma (HeLa) cells was 2-3 to $>10$-fold stronger than against leukemia and lymphocyte cells. In particular the $\left\{\left[\mathrm{SbCl}_{2}(\mathrm{MBZIM})_{4}\right]^{+} \cdot \mathrm{Cl}^{-}\right.$ $\left.\cdot 2 \mathrm{H}_{2} \mathrm{O} \cdot\left(\mathrm{CH}_{3} \mathrm{OH}\right)\right\}$ complex showed stronger activity against cancerous HeLa cells, 6 times higher than that of carboplatin.

Potassium antimonyl tartrate (PAT) inhibited human 


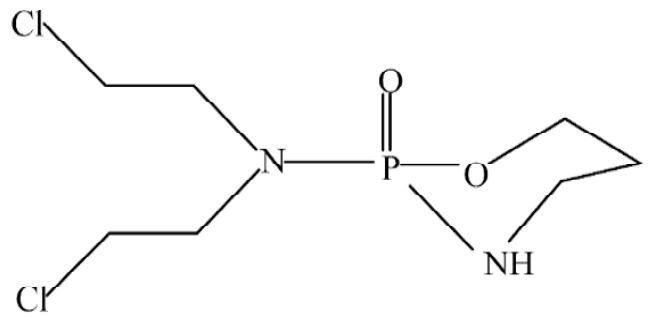

Figure 2. Chemical structure of cyclophosphamide.<smiles>O=C(O)CN(CCN(CC(=O)O)CC(=O)O)CCN(CC(=O)O)CC(=O)O</smiles>

Figure 3. Chemical structure of diethylenetriaminepentaacetic acid (Hdtpa).<smiles>O=C([O-])CN(CC(=O)[O-])CC(=O)[O-]</smiles>

Figure 4. Chemical structure of nitrilotriacetate.<smiles>C=CSc1ncccn1</smiles><smiles>S=c1nccc[nH]1</smiles>

Figure 5. Chemical structure of heterocyclic thioamide 2mercaptopyrimidine.

gastric cancer cells SGC-7901 growth significantly in a doseand time-dependent manner. PAT displayed prominent inhibitory effects with 20 and $40 \mu \mathrm{mol} / \mathrm{L}$ at $72 \mathrm{~h}$, and the cancer cell growth inhibition rates reached $54.1 \%$ and $66.6 \%$, respectively ${ }^{[16,36]}$. In vitro, this compound was found to be cytotoxic to various lung cancer cell lines with the $\mathrm{IC}_{50}$ [half maximal $(50 \%)$ inhibitory concentration] ranging from 4.2 to $322 \mu \mathrm{g} / \mathrm{mL}$ (Table 1). The complex was as effective as clinically used anticancer drugs, such as cisplatin and doxorubi$\operatorname{cin}^{[16]}$.

Like $\mathrm{As}_{2} \mathrm{O}_{3}$, antimony compounds have also been used
Table 1. Antimony potassium tartrate cytotoxicity against different tumor cell lines.

\begin{tabular}{lc}
\hline Cell line & $\mathrm{IC}_{50}(\mu \mathrm{g} / \mathrm{mL})$ \\
\hline & \\
AD-A & 4.6 \\
B K-T & 15.3 \\
HG-E & 33.1 \\
JN-M & 70.0 \\
JO-E & 66.0 \\
LD-T & 12.8 \\
LG-T & 39.3 \\
Mar & 11.2 \\
MM-I & 11.9 \\
MO-A & 9.1 \\
NCI-H & 49 \\
NCI-H & 428 \\
NCI-H & 209 \\
OS-A & 24.7 \\
RG-I & 14.9 \\
SHP-77 & 322 \\
SV-E & 14.0 \\
WL-E & 53.4 \\
\end{tabular}

for a long time in traditional Chinese medicines for the treatment of many diseases, and they have been shown to be clinically active in APL. In eukaryotic cells, resistance to arsenic and antimony is conferred by membrane transport proteins of the multidrug resistance-associated protein (MRP)1 family, which is a drug transport pump. Human MRP1, a member of the MRP family, is frequently amplified in cancer cells. It is well known that MRP1-overexpressing cells accumulate less As and Sb because of increased cellular efflux which is dependent on the presence of glutathione [37]. This is a possible mechanism by which human cells can avoid cytotoxic effects of heavy metals administered as drugs. Such a mechanism of resistance may be important for the clinical efficiency of antimonials used in the treatment of some leukemias ${ }^{[17,37]}$.

Similarly, other antileishmanial agents, such as SSG and other trivalent antimonials, including antimony trioxide (the reported toxicity of $\mathrm{SbCl}_{3}$ or $\mathrm{Sb}_{2} \mathrm{O}_{3}$ not withstanding), could induce acute promyelocytic leukemia cell NB4 apoptosis in a dose- and time-dependent manner and present therapeutic benefits to patients ${ }^{[38,39]}$. It was found that SSG is a potent inhibitor of protein tyrosine phosphatase (PTPases) in vitro and in vivo, and augments responses in hemopoietic cell lines. It was shown that induction of cellular protein tyrosine phosphorylation was less pronounced with prolonged drug incubation suggesting that either the instability of the drug under experimental conditions or the drug 
may sequentially inactivate PTPases with opposite effects on the phosphorylation of the cellular proteins. The intracellular $\mathrm{Sb}(\mathrm{V})$ to $\mathrm{Sb}$ (III) transformation of stibogluconate can result in the inactivation of the PTPases inhibitor and may account for the modest and transient induction of tyrosine phosphorylation by the drug. SSG inhibited the growth of human cancer cell lines in vitro in synergy with interferon (IFN) in IFN-resistant cancer cells. The activity of Src homology PTPase1 (SHP-1) was almost completely inhibited by SSG at $10 \mu \mathrm{g} / \mathrm{mL}$, which is comparable to the serum concentration of Leishmania treatment $(\sim 10$ $\mu \mathrm{g} / \mathrm{mL})$. The mechanism by which the drug inhibits PTPase is likely by targeting the PTPase catalytic domain of the enzymes. The drug forms a stable complex with SHP-1 in vitro, but it is not clear whether this was due to docking of the drug into a pocket structure in the PTPase domain or whether a covalent bond formation is involved. Interference with intracellular tyrosine phosphorylation resulted in the disruption of cell proliferation, differentiation, and signaling activities. Consequentially, antitumoral activity based on the finding that SSG inhibited SHP-1, anti-renal cell carcinoma (anti-RCC) potential, and the action mechanism of SSG and SSG/interleukin (IL)-2 in combination were investigated in a murine renal cancer model (Renca). Despite its failure to inhibit Renca cell proliferation in cultures, SSG induced $61 \%$ growth inhibition of Renca tumors in BALB/c mice which coincided with a 2-fold increase in tumor-infiltrating macrophages $(\mathrm{M} \phi)$. The combination of SSG and IL-2 was more effective in inhibiting tumor growth $(91 \%)$ and inducing tumor-infiltrating $\mathrm{M} \phi$ (4-fold), whereas IL-2 alone had little effect ${ }^{[40-44]}$.

No organoantimony compounds appear to have been screened for their antitumoral activity until the 1990s when Silvestru et $a l^{[45-47]}$ started working on this direction. Now the most studied antimony compounds in the context of antitumoral activity are organometallic-presenting antimonycarbon bonds.

Some diphenylantimony (III) and diphenyltin (IV) thiolates were tested both in vitro and in vivo for antitumoral activity. In vitro, against Ehrlich ascites tumors, all these compounds were almost equally effective in the inhibition of cell proliferation and viability and protein synthesis. However, the cell respiration and Ca-ATPase and lactate dehydrogenase (LDH) enzymatic activities were considerably impaired. The effects were dose and exposure time dependent. The compounds containing antimony (III) were more active than their organotin congeners ${ }^{[45-47]}$.

In vivo, tests were carried out on mice bearing Ehrlich ascites tumors and P388 leukemias. The results are shown in
Table 2, where it was found that all these compounds exhibited antitumoral properties. Three of the antimony compounds had shown marginal activity $(\mathrm{T} / \mathrm{C}<125 \%)$ and were less active than cisplatin in this model. The $\mathrm{Ph}_{2} \mathrm{SbS}_{2} \mathrm{P}\left(\mathrm{OPr}^{\mathrm{i}}\right)_{2}$ compound was most active, but presented increased toxicity at higher doses (Figure 6).

Table 2. Biological evaluation of diphenylantimony (III) thiolates against P388 leukemia in vivo.

\begin{tabular}{lcc}
\hline \multicolumn{1}{c}{ Compound } & Total dose $(\mathrm{mg} / \mathrm{kg})^{\mathrm{a}}$ & $\mathrm{T} / \mathrm{C}(\%)^{\mathrm{b}}$ \\
\hline & - & \\
Control & 4 & 100 \\
$\mathrm{NH}_{3} \mathrm{PtCl}_{2}$ (Cisplatin) & 10 & 245 \\
$\mathrm{Ph}_{2} \mathrm{SbL}_{1}$ & 5 & 123 \\
$\mathrm{Ph}_{2} \mathrm{SbL}_{2}$ & 10 & 118 \\
& 5 & 118 \\
& & 136 \\
\hline
\end{tabular}

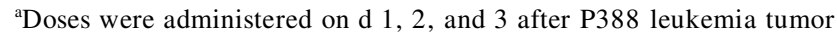
cells were transplanted into mice. ${ }^{b}$ Median survival rate of mice versus median survival rate of controls was expressed as a percentage.

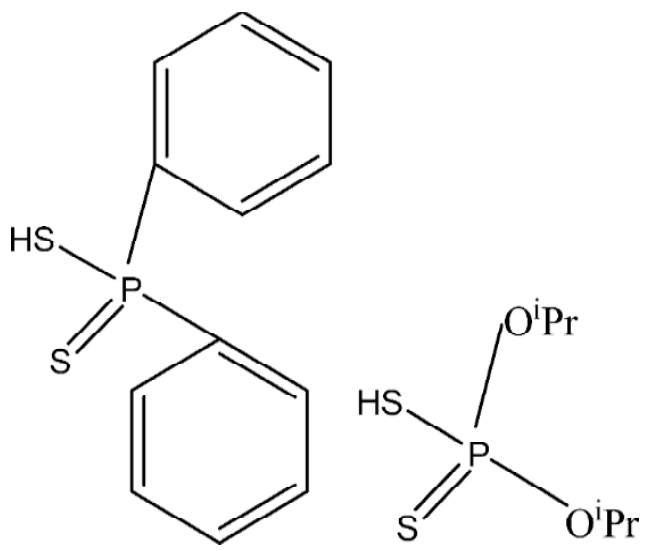

Figure 6. Diphenyldithiophosphinic acid diisopropyldithiophosphoric acid.

Later studies showed that these thiophosphinate derivatives had mutagenic potential with compound 4 at a greater extent $^{[48,49]}$.

Our group ${ }^{[50,51]}$ has published reports on the antitumoral activity of organostibine containing heterocycles; for example, selenophenyl or substituted thienyl ring (Figure 7). The compound tris(2-selenophenyl)stibine and tris(3-methyl-2-thienyl)stibine showed a significant selectivity $(>85 \%)$ for carcinogenic cell $\mathrm{K}$ and $\mathrm{U}$ growth inhibition. For compound tris(5-chloro-2-thienyl)stibine, $85 \%$ of carcinogenic cell growth inhibition ( $\mathrm{U}, \mathrm{K}$, and $\mathrm{H}$ ) was observed, but these 


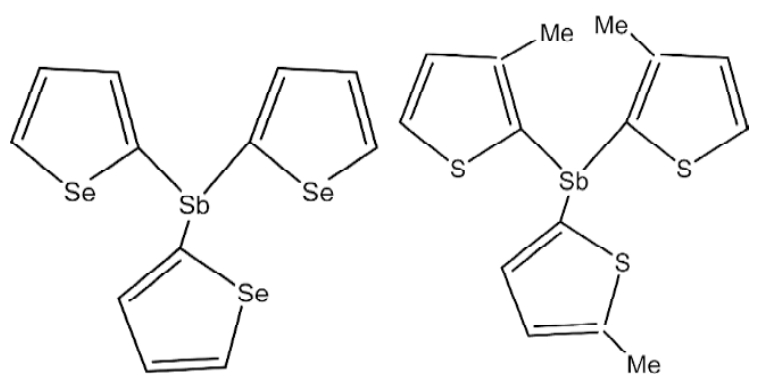

Figure 7. 2-Selenophenylstibine 3-methyl-2-thienylstibine.

compounds are highly toxic for the growth of normal lymphocytes with approximately $95 \%$ lethality.

\section{Pentavalent antimony compounds}

The trimethylantimony compounds were tested in vitro against human tumor cell lines and were found to be inactive ${ }^{[52]}$.
Cytotoxicity of antimony (V) compounds are reported in literature and one of the reports on the cytotoxicity of antimony (V) compounds focuses on the inhibitory effects of a series of triphenylantimony $(\mathrm{V})$ polyamines ${ }^{[53]}$. The different polyamines used are shown in Figure 8. Almost all the compounds displayed some inhibition, and increased inhibition was associated with increased doses. 2,6-Diaminoanthraquinone adenine has shown higher potential against the 3 cell lines BHK-21, L929, and HeLa, while the dianion derived from 2,4,-diamino5(3,4-dimethoxybenzil)pyrimidine showed greater selectivity against BHK-21.

Recently Li et al published reports on the in vitro antitumoral activities of some arylantimony derivatives of demethylcantharimide ${ }^{[54]}(\mathrm{LH}=N$-hydroxy-demethyl dehydrogencantharimide, $\mathrm{LH}=N$-hydroxy-demethylcantharimide, $n=3$, 4; $\mathrm{Ar}=\mathrm{C}_{6} \mathrm{H}_{5}, 4-\mathrm{CH}_{3} \mathrm{C}_{6} \mathrm{H}_{4}, 3-\mathrm{CH}_{3} \mathrm{C}_{6} \mathrm{H}_{4}, 2$ -<smiles>Cc1nc(N)c([N+](=O)[O-])c(N)n1</smiles><smiles>Nc1ccc2c(c1)C(=O)c1ccc(N)cc1C2=O</smiles><smiles>Nc1ccc(NC(=O)c2ccc(N)cc2)cc1</smiles>

Figure 8. Chemical structures of amines.<smiles>Nc1ncc(C(=O)C(=O)c2ccccc2)c(N)n1</smiles> 
$\mathrm{CH}_{3} \mathrm{C}_{6} \mathrm{H}_{4}$, 4- $\mathrm{ClC}_{6} \mathrm{H}_{4}$, 4- $\mathrm{FC}_{6} \mathrm{H}_{4}$ ), arylhydroxamates ( $\mathrm{LH}=$ hydroxamic acid; Figure 4$)^{[55]}$, and a series of derivatives of exo-7-oxa-bicyclo(2,2,1)heptane(ene)-3-arylamide2 -acid ${ }^{[56]}$, which are analogs of demethylcantharidin, and demethyldehydrogencantharidin ${ }^{[57]}$.

Tetraarylantimony derivatives of demethylcantharimide have relatively higher antitumoral activity against the 6 cancer cells (HL-60, PC-3MIE8, Human Gastric Carcinoma (BGC823), Breast Tumor MDA-MB-435, Bel-7402, HeLa) than the triarylantimony derivatives of demethylcantharimide. When Ar is $4-\mathrm{ClC}_{6} \mathrm{H}_{4}$, compounds $\mathrm{c}$ and e have relatively higher antitumoral activity. When compared with cisplatin, compound a and tetraarylantimony derivatives of demethylcantharimide, namely compounds b, c, d, and h, have very high antitumoral activity against some cancer cells ${ }^{[54]}$.

The results of the bioassay showed that these derivatives exhibited antitumoral activities against the different human cancer cells in vitro ${ }^{[55]}$. The antitumoral activities are also affected by the nature of the arylantimony. The tetraarylantimony benzohydroxamate, namely compound a, has much higher antitumoral activity against the 3 human cancer cells (HL-60, BGC-823, MDA-MB-435) than the triarylantimony benzohydroxamates. In addition, compound $\left.\left(\mathrm{HNEt}_{3}\right)^{+}\left(\mathrm{Ar}_{3} \mathrm{Sb} \text { [arylhydroxamate }\right]_{2}\right)^{-}$, where $\mathrm{Ar}$ is $4-\mathrm{ClC}_{6} \mathrm{H}_{4}$, is more potent against BGC-823 cells (Figure 9).

Five human neoplastic cell lines (HL-60, KB, Bel-7402, BGC-823, and HCT-8) were used to screen derivatives of exo7-oxa-bicyclo(2,2,1)heptane(ene)-3-arylamide-2-acid. The results indicated that these compounds at $10 \mu \mathrm{mol} / \mathrm{L}$ show certain antitumoral activities in vitro ${ }^{[56]}$.

Preliminary antitumoral activity tests show that tetraphenylantimony $(\mathrm{V})$ derivatives of demethylcantharidin and demethyldehydrogencantharidin have significant antitumoral activities in vitro against 5 human neoplastic cell lines ${ }^{[57]}$.

In an another report, the antitumoral potential of different triarylantimony derivatives of triphenylgermanyl propionate were investigated ${ }^{[58]}$. These compounds have relatively higher antitumoral activities against cancer cells in vitro than triphenylgermanylpropionic acid. The results indicate that the antitumoral activities are affected by the nature of the aryl and the triphenylgermanylpropionic acids. The same group ${ }^{[59,60]}$ extended their studies to antimony ferrocenylcarboxylate and $\mathrm{N}$-phenylglycinate derivatives. Three human neoplastic cell lines (HCT-8, Bel-7402, and KB) were used to screen these compounds. The results indicated that these complexes at $5 \mu \mathrm{mol} / \mathrm{L}$ show relatively good antitumoral activities in vitro. When the ferrocenylcarboxylate group is $\mathrm{C}_{5} \mathrm{H}_{5} \mathrm{FeC}_{5} \mathrm{H}_{4} \mathrm{C}(\mathrm{Me})=\mathrm{CHCOO}^{-}$, it has relatively higher antitumoral activities, in particular, the activity of compound<smiles></smiles>

Compound (a) $\mathrm{Ar}=4-\mathrm{CH}_{3} \mathrm{C}_{6} \mathrm{H}_{4}$

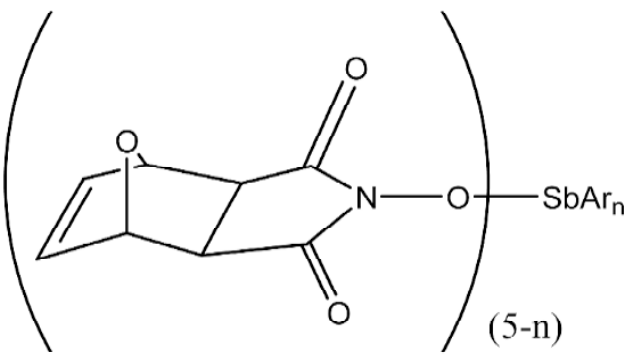

Compounds (b) $\mathrm{Ar}=\mathrm{C}_{6} \mathrm{H}_{5}$, (c) $4-\mathrm{ClC}_{6} \mathrm{H}_{4}$

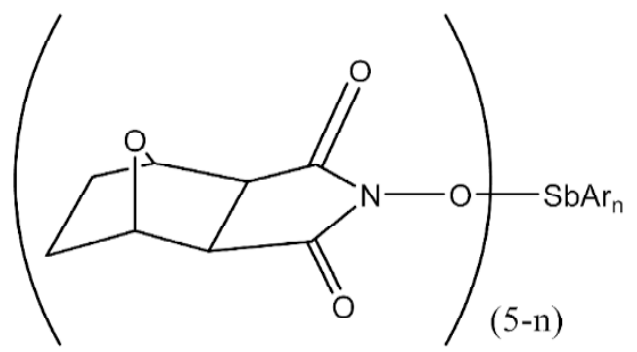

Compounds (d) $\mathrm{Ar}=\mathrm{C}_{6} \mathrm{H}_{5}$, (e) $4-\mathrm{ClC}_{6} \mathrm{H}_{4}$

Figure 9. General structures of antimony (V) compounds.

tris-( $p$-chlorophenyl)antimony(ferrocenylcarboxylate) against HCT-8 cells is higher than that of cisplatin.

Carraher et $a l^{[61]}$ synthesized polymers containing metal complex formed from triphenylantimony dichloride and thiopyrimidine, and preliminary evaluation showed that these polymers exhibited both antitumoral and antibacterial properties. The polymers showed inhibition of BalK/3T3 cells at concentrations below $10 \mu \mathrm{g} / \mathrm{mL}$. Additionally, products from $\mathrm{Ph}_{3} \mathrm{SbBr}_{2}$ and cephalexin showed good inhibition of $\mathrm{Balb} / 3 \mathrm{~T} 3$ cells to $2 \mu \mathrm{g} / \mathrm{mL}$, and those from $\mathrm{Me}_{3} \mathrm{SbBr}_{2}$ and cephalexin show good inhibition to $15 \mu \mathrm{g} / \mathrm{mL}$. The structure for the $\mathrm{Ph}_{3} \mathrm{SbCl}_{2}$ and cephalexin product is given later (Figure 10).

A number of antimony (V) polyamines were synthesized, and it was found that these materials also effectively inhibited HeLa cells at concentrations of approximately $5 \mu \mathrm{g} / \mathrm{mL}$.

\section{Conclusion}

A variety of antimonials with different antitumoral activi- 


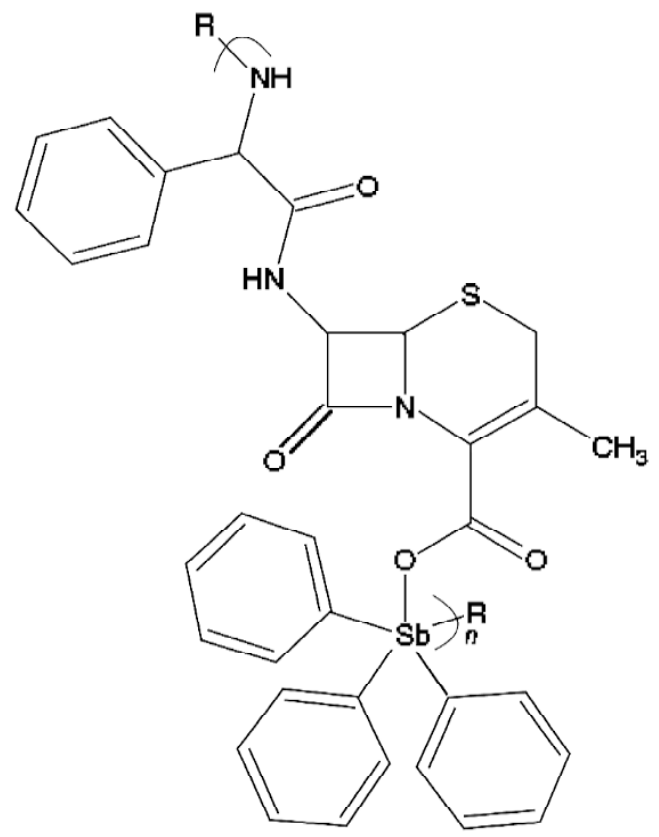

Figure 10. $\mathrm{Ph}_{3} \mathrm{SbCl}_{2}$ and cephalexin compound.

ties are known. These antimonials have a diverse application, even though little research has been done on their possibilities in this respect. It might be feasible to develop more specific and effective inhibitors for phosphatase-targeted anticancer therapeutics through the screening of SSG-related compounds comprised of antimony conjugated to different organic moieties. SSG is a potent PTPases inhibitor, and as an enhancer of cytokine signaling, appears to be a better inhibitor than suramin. This suggests potential novel clinical applications of the drug in a variety of situations where increased cytokine responses are beneficial. It is clear that the exploration of the antitumoral activity of antimony compounds appear to hold the promise, and therefore, is an area certainly deserving of more research effort.

\section{References}

1 Desoize B. Metals and metal compounds in cancer treatment. Anticancer Res 2004; 24: 1529-44.

2 Rosenberg B, Van Camp L, Trosko JE, Mansour VH. Platinum compounds: a new class of potent antitumour agents. Nature 1969; 222: 385-6.

3 Allen TM. Ligand-targeted therapeutics in anticancer therapy. Nat Rev Cancer 2002; 2: 750-63.

4 Gielen M, editor. Metal based antitumour drugs. London: Freund Publishing House Ltd; 1988.

5 Keppler BK, editor. Metal complexes in cancer chemotherapy. Weinheim Germany: VCH; 1993. p1-8.

6 Köpf-Maier P. Complexes of metals other than platinum as antitumour agents. Eur J Clin Pharmacol 1994; 47: 1-16.
7 Barnard CFJ, Fricker SP, Vaughan OJ. Medical applications of inorganic chemicals. In Thompson D, editor. Insights into specialty inorganic chemicals. Cambridge: Royal Society of Chemistry; 1995. p35-60.

8 Sadler PJ, Guo Z. Metal complexes in medicine: design and mechanism of action. Pure Appl Chem 1998; 70: 863-71.

9 Guo Z, Sadler PJ. Metals in medicine. Angew Chem Int Ed Engl 1999; 38: 1512-31.

10 Meriem A, Willem R, Biesemans M, Mahieu B, Vos de D, Lelievald $\mathrm{P}$, et al. Synthesis, characterization and in vitro antitumour activity of dibutyltin(IV) derivatives of some aromatic carboxylic acids, including aspirin. Appl Organomet Chem 1991; 5: 195-201.

11 Brutkiewicz RR, Suzuki F. Biological activities and antitumour mechanism of an immunopotentiating organogermanium compound, Ge-132 (review). In Vivo 1987; 1: 189-204.

12 Celaries B, Gielen M, Vos de D, Rima G. In vitro antitumour activity of some organogermanium radioprotectors. Appl Organomet Chem 2003; 17: 191-3.

13 Gielen M, Willem R, Bouhdid A, Vos de D, Inventors; Pharmachemie B.V., asignee,. Preparation of Aaromatic fluorine-containing organotin compounds as anti-tumour agents. Eur Patent 57009211996 Mar 13.

14 Gielen M, Willem R, Biesemans M, Kemmer M, Vos de D, Inventors; Pharmachemie B.V., asignee, Antitumour tin poly oxaalkanecarboxylates, preparation thereof, and compositions containing them. PCT Int Appl 170065832000 Feb 10.

15 Tabassum S, Pettinari CJ. Chemical and biotechnological developments in organotin cancerchemotherapy. J Organomet Chem 2006; 691: 1761-6.

16 Duffin J, Camping B J. Therapy and disease concepts: the history (and future) of antimony in cancer. J Hist Med 2002; 57 : $61-78$.

17 Tiekink ERT. Antimony and bismuth compounds in oncology. Crit Rev Onco Hemat 2002; 42: 217-24

18 Tracy JW, Webster LT. Drugs used in the chemotherapy of protozoal infections. In: Hardman JG, Limbird LE, Molinoff PB, Ruddon RW, Gilman AG. editors. The pharmacological basis of therapeutics, 9th ed. New York: Mcgraw-Hill; 1995; p 9871008.

19 Berman DJ. Chemotherapy for Leishmaniasis: boichemical mechanisms, clinical efficacy, and future strategies. Rev Infect Dis 1988; 10: 560-86.

20 Tester-Dalderup CBM. Antiprotozoal drugs. In: Dukes MNG, editor. Meyler's side effects of drugs, 13th ed. Amsterdam: Elsevier; 1996; p 799-842.

21 Lee MB, Gilbert HM. Current approaches to Leishmaniasis. Infect Med 1999; 16: 37-45.

22 Lugo A, Anez N, Petit de Pena Y, Burguera JL, Burguera M. Antimony determination in tissues and blood serum of hamsters infected with Leishmania garnhami and treated with meglumine antimoniate. Annals Trop Med Parasitol 1994; 88: 37-41.

23 Demicheli C, Frézard F, Lecouvey M, Garnier-Suillerot A. Antimony(V) complex formation with adenine nucleosides in aqueous solution. Biochim Biophys Acta 2002; 1570: 192-8.

24 Hsu B, Chou CH, Chen JT, Shen ML. Studies on antitumour action of antimony-complexones. Chin Med J 1963; 82: 15563. 
25 Hsu B, Chou CH, Chen JT, Shen ML. Studies on antitumour action of antimony complexones. Acta Unio Intern Contra Cancrum 1964; 20: 245-8.

26 Hsu B, Kao YS, Tsai JS, Chou CH, Liu MC, Shen ML, et al. Pharmacological studies of several new antitumour agents. Sci Sin 1964; 13: 789-800.

27 Jasmin C, Cherman JC, Herve G, Teze A, Souchay P, Boy- Loustau $\mathrm{C}$, et al. In vivo inhibition of murine leukemia and sarcoma viruses by the heteropolyanion 5-tungsto-2-antimoniate J Natl Cancer Inst 1974; 53: 469-74.

28 Lidereau R, Bouchet C, Sinoussi F, Saracino R, Cherman JC. Current Chemotherapy Proc 1978; 2 : 1323-6.

29 Joesten MD, Najjar R, Hebrank G. Metal complexes of alkylating agents-(III). Complexes by cyclophosphamides. Polyhedron 1982; 1: 637-9.

30 Hu SZ, Tu LD, Huang YQ, Li ZX. Studies on the antitumour antimony (III) aminopolycarboxylic acid chelates. Crystal structures of $\mathrm{M}[\mathrm{Sb}$ (pdta) $] \cdot \mathrm{H}_{2} \mathrm{O}(\mathrm{M}=\mathrm{Na}+, \mathrm{NH} 4+$., pdta=propylenediaminetetraacetic acid). Inorg Chim Acta 1995; 232: 161-5.

31 Hu SZ, Fu YM, Xu B, Tang WD, Yu WJ. Studies on the antitumour antimony (III) triaminocarboxylic complexonates. Crystal structures of $\mathrm{NH}_{4}[\mathrm{Sb}$ (Hdtpa) $] . \quad \mathrm{H}_{2} \mathrm{O}$ and $\mathrm{Na}[\mathrm{Sb}$ (Hdtpa) $] . \quad 4.5 \mathrm{H}_{2} \mathrm{O}$ (dtpa=diethylenetriaminepenta acetic acid). Main Group Metal Chem 1997; 20: 169-80.

32 Popov AM, Davidovich RL, Li IA, Skulbeda AV, Hu SZ. Cytotoxic and antitumour activity of antimony (III) nitrilotriacetate complexes $\mathrm{M}_{2} \mathrm{Sb}(\mathrm{Nta})$ (HNta) $\mathrm{nH}_{2} \mathrm{O}\left(\mathrm{M}=\mathrm{NH}_{4}, \mathrm{Na}\right.$., $\left.\mathrm{n}=1,2\right)$. Pharm Chem J 2005; 39: 119-21.

33 Tofazzal M, Tarafder H, Ali AM, Elias MS, Crouse K, Silong S. Coordination chemistry and biological activity of bidentate and quadridentate nitrogen- sulphur donor ligands and their complexes. Trans Met Chem 2000; 25: 706-10.

34 Hadjikakou S K, Antoniadis CD, Hadjiliadis N, Kubicki M, Binolis J, Karkaounas S, et al. Synthesis and characterization of new water stable antimony(III) complex with pyrimidine-2-thione and in vitro biological study. Inorg Chim Acta 2005; 358: 28616.

35 Ozturk I I, Hadjikakou SK, Hadjiliadis N, Kourkoumelis N, Kubicki M, Baril M, et al. Synthesis, structural characterization, and biological studies of new antimony (III) complexes with thiones. The influence of the solvent on the geometry of the complexes. Inorg Chem 2007; 46: 8652-61

$36 \mathrm{Xu} \mathrm{S}$, Guo G, Wang J, Huang Y. Effects of potassium antimonyl tartrate on proliferation and apoptosis in vitro of human gastric cancer. Disi Junyi Daxue Xuebao 2004; 25: 1464-6.

37 Salerno M, Suillerot AG. Resistance to arsenic-and antimony based drugs. Bioinorg Chem Appl 2003; 1: 189-98.

38 Yu W, Sun B, Chai Y, Zhao Z, Liu X, Ji Z, et al. Apoptosis of acute promyelocytic leukemia cell NB4 induced by different kinds of antimonials. Disi Junyi Daxue Xuebao 2003; 24: 338-41.

39 Pathak MK, Hu X, Yi T. Effects of sodium stibogluconate on differenciation and proliferation of human myeloid leukemia in vitro. Leukemia 2002; 16: 2285-91.

40 Muller S, Miller WH, Dejean A. Trivalent antimonials induce degradation of the PML-RARa oncoprotein and reorganization of the promyelocytic leukemia nuclear bodies in acute promyelocytic leukemia NB4 cells. Blood 1998; 92: 4308-16.

41 Yi T, Pathak MK, Lindner DJ, Ketterer MF, Farver C, Borden
EC. Anticancer activity of sodium stibogluconate in synergy with IFNs. J Immunol 2002; 169: 5978-85.

42 Fan K, Zhou M, Pathak MK, Lidner DJ, Aluntas CJ, Tuohy VK, et al. Sodium Stibogluconate interacts with IL-2 in anti-Renca tumour action via $\mathrm{T}$ cell-dependent mechanism in connection with induction of tumour-infiltrating macrophages. J Immunol 2005; 169: 7003-8.

$43 \mathrm{Yu}$ W, Sun B, Chai Y, Zhao Z, Liu X, Ji Z, et al. Apoptotic induction of acute promyelocytic leukemia cell NB4 by antimony trioxide. Xibao Yu Fenzi Mianyixue Zazhi 2002; 18: 5924.

44 Yi T. Inhibition of protein tyrosine phosphatase by leishmaniasis agents and their use in combination with cytokines for treatment of cancer and other diseases. PCT Int Appl 2003; 144.

45 Silvestru C, Socaciu C, Bara A, Haiduc I. The first organoantimony (III) compounds possessing antitumour properties: diphenylantimony(III) derivatives of dithiophosphorus ligands. Anticancer Res 1990; 10: 803-4

46 Bara A, Socaciu C, Silvestru C, Haiduc I. Activity of some diphenyltin(IV) and diphenylantimony(III) derivatives on in vitro and in vivo Ehrlich ascites tumour Antitumour organometallics. Anticancer Res 1991; 11: 1651 -6.

47 Socaciu C, Bara A, Silvestru C, Haiduc I. Antitumour organometallics. II. Inhibitory effects of two diphenyl-antimony (III) dithiophosphorus derivatives on in vitro and in vivo Ehrlich ascites tumour. In Vivo 1991; 5: 425-8.

48 Keppler BK, Silvestru C, Haiduc I. Antitumour organometallics. III. In vivo activity of diphenylantimony(III) and diorganotin (IV) dithiophosphorus derivatives against P388 leukemia. MetalBased Drugs 1994; 1: 73-7.

49 Socaciu C, Pasca I, Silvestru C, Bara A., Haiduc I. Antitumour organometallics. IV. The mutagenic potential of some diphenylantimony(III) dithiophosphorus derivatives. MetalBased Drugs 1994; 1: 291-7.

50 Sharma P, Rosas N, Cabrera A, Toscano A, Silva MJ, Pérez D, et al. First synthesis and structural report on selenophen-2-yl containing pnictogens: Biological Activities of tris (selenophen-2yl)stibine. J Organomet Chem 2005; 690: 3286-91.

51 Sharma P, Rosas N, Cabrera A, Toscano A, Silva MJ, Hernández $\mathrm{S}$, et al. Substituted thienyl stibines and bismuthines: syntheses, structures and cytotoxicity. Appl Organomet Chem 2005; 19: 1121-6.

52 Silvestru C, Haiduc I, Tiekink ERT, de Vos D, Biesemans M, Willem R, et al. Synthesis, structural characterization and in vitro antitumour properties of triorganoantimony( $\mathrm{V})$ disalicylates: crystal and molecular structures of [5-Y-2-(HO)- $\left.\mathrm{C}_{6} \mathrm{H}_{3} \mathrm{COO}\right]_{2} \mathrm{SbMe}_{3}$ ( $\mathrm{Y}=\mathrm{H}, \mathrm{Me}, \mathrm{MeO}$ ). Appl Organomet Chem 1995; 9: 597-607.

53 Carraher CE Jr, Nass MD, Giron DJ, Cerutis DR. Structrual and biological characterization of antimony(V) polyamines. J Macromol Sci Chem 1983; 19: 1101-20.

54 Wang GC, Xiao J, Lu Y, Li JS, Cui JR, Wang RQ, et al. Synthesis, crystal structures and in vitro antitumour activities of some arylantimony derivatives of analogues of demethylcantharimide. J Organomet Chem 2004; 689: 1631-8.

55 Wang GC, Lu YN, Xiao J, Yu L, Song HB, Li JS, et al. Synthesis, Crystal structure and in vitro antitumour activities of some organoantimony arylhydroxamates. J Organomet Chem 2005; 690: $151-6$. 
56 Li JS, Ma YQ, Cui JR, Wang RQ. Synthesis and in vitro antitumour activity of some tetraphenylantimony derivatives of exo-7-oxabicyclo $[2,2,1]$ heptane(ene)-3- arylamide -2-acid. Appl Organomet Chem 2001; 15: 639-45.

57 Li JS, Ma YQ, Yu L, Cui JR, Wang RQ. Synthesis, spectroscopic characterization, and in vitro antitumour activity of tetraphenylantimony derivatives of analogs of demethylcantharidin and demethyl-dehydrogencantharidin. Synth React Inorg Met Org Chem 2002; 32: 583-93.

$58 \mathrm{Ma}$ YQ, Li JS. Synthesis and in vitro antitumour activity of triarylantomony di (triphenylgermanyl propionates). Main Group Met Chem 2001; 24: 235-8.

59 Yu L, Ma YQ, Liu RC, Wang GC, Li JS, Du GH, et al. Synthesis, characterization and in vitro antitumour activity of some arylantimony ferrocenylcarboxylate derivatives and the crystal structures of $\left[\mathrm{C}_{5} \mathrm{H}_{5} \mathrm{FeC}_{5} \mathrm{H}_{4} \mathrm{C}\left(\mathrm{CH}_{3}\right)=\mathrm{CHCOO}\right]_{2} \mathrm{Sb}\left(\mathrm{C}_{6} \mathrm{H}_{4} \mathrm{~F}-4\right)$ and $\left.\left(\mathrm{C}_{5} \mathrm{H}_{5} \mathrm{FeC}_{5} \mathrm{H}_{4}\right) \mathrm{C}_{6} \mathrm{H}_{4} \mathrm{COO}\right]_{2} \mathrm{Sb}\left(\mathrm{C}_{6} \mathrm{H}_{4} \mathrm{~F}-4\right)_{3}$. Polyhedron 2004; 23 : 823-9.

$60 \mathrm{Yu}$ L, Ma YQ, Wang GC, Li JS. Synthesis and in vitro antitumour activity of some triarylantimony di(N-phenylglycinates). Heteroatom Chem 2004; 15: 32-6.

61 Slegmann-Louda DW, Carraher CE Jr, Quinones Q, McBride G. Preliminary evaluation of organoarsenic and organoantimony polymers derived from cephalexin as potential anticancer drugs. PMSE Preprints 2003; 88: 390-2. 